\title{
ALZHEIMER'S DISEASE IN BRAZILIAN ELDERLY HAS A RELATION WITH HOMOCYSTEINE BUT NOT WITH MTHFR POLYMORPHISMS
}

\author{
Vanessa Cavalcante da Silva', Flávio José da Costa Ramos', \\ Elizabete Malaquias Freitas', Paulo Roberto de Brito-Marques², \\ Márcia Nery de Holanda Cavalcanti², Vânia D'Almeida³, \\ José Eulálio Cabral-Filho ${ }^{4}$, Maria Tereza Cartaxo Muniz ${ }^{1}$
}

\begin{abstract}
Objective: To investigate the association between total plasma homocysteine concentration, C677T and A1298C polymorphisms in MTHFR gene and Alzheimer's disease (AD) development. Method: Forty-thre patients with probable (63\%) and possible (37\%) AD and 50 non-demented controls were evaluated. Groups did not differ as to gender, age, scholar years, diabetes, alcohol and coffee intake and physical activity. Total plasma homocysteine (Hcy) levels were determined by HPLC and genotyping for MTHFR by PCR/RFLP. Mann-Whitney "U" test was used to compare quantitative variable, Fisher-Freeman-Halton test to compare genotypes and allele proportions and Chi-square test to other qualitative variables. Results: $A D$ patients presented higher total plasma Hcy levels than controls and the diffe rence was statistically significant. No differences in the C677T and A1298C MTHFR polymorphisms distributions were found between patients and controls. Plasma homocysteine concentration did not change with MTHFR genotypes. Conclusion: Our data confirms the association between increased plasma Hcy concentration and AD and suggests that neither C677T nor A1298C MTHFR polymorphisms contributed to genetic susceptibility for $A D$ in elderly individuals in the Northeast of Brazil.
\end{abstract}

KEY WORDS: homocysteine, MTHFR, Alzheimer's disease.

\section{A doença de Alzheimer em idosos brasileiros tem relação com homocisteina mas não com poli- morfismos MTHFR}

RESUMO - Objetivo: Investigar a associação entre a concentração plasmática total de homocisteína (Hcy), os polimorfismos C677T e A1298C do gene MTHFR e o desenvolvimento da Doença de Alzheimer (AD). Método: Foram avaliados 43 pacientes com doença de Alzheimer possível (37\%) e provável $(63 \%)$ e 50 cont roles não dementes, não divergentes quanto ao sexo, idade, anos de escolaridade, diabetes, consumo de álcool e de café e vida sedentária. Os níveis plasmáticos de homocisteína foram determinados por HPLC e a genotipagem para MTHFR por PCR/RFLP. A comparação dos níveis de homocisteína foi realizada pelo teste "U" Mann-Whitney, a comparação das proporções dos genótipos e alelos pelo teste de Fisher-FreemanHalton e as demais variáveis qualitativas, pelo teste do qui-quadrado. Resultados: Os pacientes AD apresentaram níveis mais elevados de Hcy plamática total do que os controles e a diferença entre os grupos foi estatisticamente significante. Não houve diferença nas distribuições genotípicas C677T e A1298C entre pacientes e controles. A concentração de Hcy não variou com os genótipos. Conclusão: Nossos dados confi rmam a associação de concentração elevada de Hcy plasmática com DA e sugerem que os polimorfismos C677T e A1209C não contribuem para a susceptibilidade genética a DA em idosos do Nordeste do Brasil.

PALAVRAS-CHAVE: homocisteína, MTHFR, doença de Alzheimer.

Metilenetetraidrofolate reductase (MTHFR) is an enzyme of the folate metabolism that reduces 5,10 metilenetetraidrofolate $(5,10$-mTHFR) to 5-metiltetraidrofolate (5-mTHF), an important co-factor to homocysteine (Hcy) methylation. Mutations in MTHFR gene (C677T and $A 1298 C$ ) result in aminoacids substitutions that lead to a decreased enzyme activity, reducing the $5 \mathrm{mTHF}$ availability ${ }^{1,2}$. These muta-

'Instituto de Ciências Biológicas da Universidade de Pernambuco, Recife PE - Brazil; ²Unidade de Neurologia do Comportamento do Departamento de Neurologia, Faculdade de Ciências Médicas da Universidade de Pernambuco, Recife PE - Brazil; ${ }^{3}$ Departamento de Pediatria da Universidade Federal de São Paulo, São Paulo SP - Brazil; ${ }^{4}$ Instituto Materno-Infantil de Pernambuco, Recife PE Brazil.

Received 21 September 2005, received in final form 24 July 2006. Accepted 12 September 2006.

Dra. Maria Tereza Cartaxo Muniz - Instituto de Ciências Biológicas da Universidade de Pernambuco - Rua Arnóbio Marques 310 50100-130 Recife PE - Brasil. E-mail: tcartaxo.upe@hotmail.com 
tions have got polymorphic proportions in human populations ${ }^{3}$. As a consequence of the MTHFR dysfunctions, an increased Hcy level in plasma has been expected which, in turn, produces a cytotoxic effect ${ }^{4}$. Hcy belongs to a thiol group and it might produce self-oxidations resulting in oxygen specimens such as hydrogen peroxide and radical anionic superoxides, probably responsible for cerebral oxidative stress in Alzheimer's disease (AD) and other neuro degenerative disord er $\mathrm{s}^{5}$. AD patients have brain atrophy characterized by neurofibrillany tangles, senile plaques and neuronal cell loss. Neurofibrillarytangles are insoluble phosphorylated helical filaments (PHF) deposits which derive from tau protein hyperphosphorylated that lost property to polymerise tubulin ${ }^{6}$. The ruptures in cytoskeleton derived from these alterations contribute to neuronal death ${ }^{7}$. Senile plaques are extracellular deposits of $\beta$-amyloid material made $f$ rom proteolytic fragments of a larger precursor, the $\beta$-amyloid precursor protein (APP) 8 .

Epidemiological studies have reported an association between increased plasma Hcy level and $A D^{9,10}$ and indicate a relationship between hyperhomocysteinemia and MTHFR polymorphisms or between homozygous genotype 677TT and DA ${ }^{11,12}$. Researches in $A D$ which use animal models have demonstrated that folate deficiency and higher level Hcy increase sensibility to $\beta$-amyloid toxicity in neurons, PHF and hyperphosphorilated tau protein deposits and apoptosis $^{13}$. In spite of these evidences, contradictory data in the literature indicate that the role of elevated Hcy and MTHFR polymorphisms as contributors factors to the etiopathogenesis of the disease remains unclear ${ }^{14-16}$.

Hyperhomocysteinemia such as in $A D$ result from a complex interaction of acquired and genetic factors which may vary according to ethnicity, enviro nmental factors and genetic background. So, this study was carried out to investigate if C677T and A1298C MTHFR polymorphisms as well as increased plasma Hcy level play as risk factors to $A D$ in elderly individuals in the Northeast of Brazil.

\section{METHOD}

Subjects - The studied group consisted of 42 individuals (7 males and 35 females) of which, $69 \%$ were white people, with ages ranging from 56 to 86 years (mean age 73.8 years, $S D=7.2$ ). Of these total, $63 \%$ were probable $A D$ and $37 \%$ possible $A D$, according to NINCDS-ADRDA criteria ${ }^{17}$. Patients were selected from the Behavorial Neurobiology Unit - Department of Neurology - University of Pernambuco (Brazil). The control group consisted of 50 individuals (13 males and 37 females) of which $40 \%$ were white people, aged 61-89 (mean age 73.9; SD=6.5). They were selected in the community to which the University belongs. Individuals who had undergone vitamin or hormonal therapy were bedridden or had hyperthension were excluded from the study.

Although Brazil is a racial melting pot and the assignment of race, a very subjective issue in this country, patients and controls were classified as non- white $(40 \%)$, just by visual inspection, whenever traces of racial mixture were evident. Individuals had different proportions of white, black and indigen blood.

Data regarding formal education, family history of dementia, diabetes, smoking habit, alcohol intake and no physical activity were collected through interviews.

This study was approved by the Ethnics Committee of the State University of Pernambuco and a written consent was obtained from every individuals participating in the study.

Plasmatic homocysteine and genotyping - Total Hcy concentrations in plasma were measured by HPLC with fluo rescence detection. Pro ce d u res for the sample preparation were reported by Pfiffer et al. ${ }^{18}$. DNA was isolated by using a Wizard Genomic DNA Purification kit (Promega) and the genotyping protocols for detection of the MTHFR mutations were the ones described by Frosst et al. ${ }^{19}$ for C677T and by Skibola et al. ${ }^{20}$ for A1298C.

Statistical analysis - Previous to statistical analysis proper, data were tested for normality (Kolmogorov-Smimov test). Since distributions failed to meet this criterion, MannWhitney " $U$ " test was used to compare groups as to quantitative variable; Fisher-Freeman-Halton test to compare genotype and allele proportions; Chi-square test to other qualitative variables. Null hypothesis was rejected when $\mathrm{p}<0.05$. The Minitab 3.0 and Stat Exact Statistical softwares were employed for data processing.

\section{RESULTS}

Table 1 illustrates the biosocial-demographic data collected and only race/color, family history of dementia and smoking habits showed significant differences between $A D$ and control. Since some these features are recognized as risk factors for vascular diseases ${ }^{21}$ and possible AD has vascular components, we decided to compare possible and probable AD and did not find differences between them except in family history (probable $A D, 55 \%$; possible $A D, 7.7 \%$; $p=0.002$ ). Because there were no statistical differences as to other factors, possible and probable AD patients were analyzed together.

The frequencies of the MTHFR genotypes for both loci C677T and A1298C and respective alleles are shown in Table 2. The distributions of the MTHFR genotypes correspond to those expected by HardyWeinberg equilibrium in both AD patients and con- 
Table 1. Bio-social demographic and clinical data of DA patients and controls.

\begin{tabular}{lccc}
\hline Variable & $\begin{array}{c}\text { Patients } \\
(\mathrm{N}=42)\end{array}$ & $\begin{array}{c}\text { Controls } \\
(\mathrm{N}=50)\end{array}$ & $\begin{array}{c}\mathrm{p} \\
\text { Pac x Control }\end{array}$ \\
\hline Sex F,\% & 83 & 74 & 0.2797 \\
Age, mean (DP) & $73.8(\mathrm{SD7} .2)$ & $73.9(\mathrm{SD} 6.5)$ & 0.6664 \\
Colour, white,\% & 69 & 40 & $0.0101^{*}$ \\
Scholar years 0-8,years, \% & 50 & 64 & 0.1759 \\
Dementia familial history, \% & 40 & 6 & $0.0002^{*}$ \\
Diabetes, +, \% & 7 & 6 & 0.8250 \\
Smoking habits,+,\% & 5 & 24 & $0.0234^{*}$ \\
Alcohol intake, + \% & 9.5 & 18 & 0.2450 \\
Sedentarism, +, \% & 76.2 & 60 & 0.0989 \\
\hline $\begin{array}{l}\text { Qualitative variable, by chi-square test and quantitative variable, by Mann-Whitney “U” test. *Statistically } \\
\text { significant. }\end{array}$ & & &
\end{tabular}

Table 2. Distribution of $A D$ patients and controls according to MTHFR genotypes and alleles proportions.

\begin{tabular}{lccccc}
\hline \multirow{2}{*}{$\begin{array}{l}\text { Genotypes } \\
\text { and alleles }\end{array}$} & \multicolumn{2}{c}{ AD Patients } & \multicolumn{2}{c}{ Control } & p \\
\hline C677T & N (43) & $\%$ & N (50) & $\%$ & \\
CC & 19 & 44.2 & 25 & 50.0 & \\
CT & 19 & 44.2 & 23 & 46.0 & 0.43 \\
TT & 5 & 11.6 & 2 & 4.0 & \\
Allele 677T & 29 & 34.0 & 27 & 27.0 & 0.31 \\
A1298C & & & & & \\
AA & 21 & 48.8 & 27 & 54.0 & \\
AC & 21 & 48.8 & 22 & 44.0 & 0.84 \\
CC & 1 & 2.4 & 1 & 2.0 & \\
Allele 1298C & 23 & 27.0 & 24 & 24.0 & 0.66 \\
\hline Fisher-Freemann-Halton test & & & &
\end{tabular}

Table 3. Homocysteine levels in AD patients and controls according MTH FR genotypes.

\begin{tabular}{cccc}
\hline Genotypes & $\begin{array}{c}\text { AD patients } \\
(\mathrm{N}=43) \\
\overline{\mathrm{X}}_{ \pm} \mathrm{SD}\end{array}$ & $\begin{array}{c}\text { Control } \\
(\mathrm{N}=50)\end{array}$ & $\mathrm{p}$ \\
\hline$\overline{\mathrm{X}}_{ \pm} \mathrm{SD}$ & & \\
\hline C677T & & & \\
CC & $18.98 \pm 10.2$ & $15.57 \pm 6.3$ & 0.22 \\
$\mathrm{CT}$ & $16.89 \pm 4.3$ & $14.50 \pm 3.9$ & 0.08 \\
TT & $21.29 \pm 5.8$ & $22.30 \pm-$ & - \\
A1298C & & & \\
AA & $18.66 \pm 7.0$ & $15.11 \pm 4.9$ & 0.03 \\
AC & $10.00 \pm 8.5$ & $15.49 \pm 6.9$ & 0.16 \\
CC & $17.64 \pm-$ & $18.25 \pm-$ & - \\
Total & $18.31 \pm 7.6$ & $15.34 \pm 75.4$ & 0.02 \\
\hline Comparisons: Mann-Whitney "U" test. & &
\end{tabular}


trols, indicating that the allelic combinations were made casually. Although the 677TT homozygous frequency was higher in patients (11.6\%) than in controls $(677 T \mathrm{~T}=4 \%)$, as expected, the difference in genotypes distribution was not significant $(p>0.05)$. No statistical diffe rences were observed in $\mathrm{A} 1298 \mathrm{C}$ genotypes and alleles, either ( $p>0.05$ ).

Considering that allelic frequencies vary with ethnicity, white and non-white individuals were examined as to the proportions of genotypes and alleles. Genotype carriers of mutant allele 677T (TT+CT), in relation to $677 \mathrm{CC}$ genotype had higher prevalence in white patients $(p=0.014)$. Controls did notpresent this relation $(p=0.77)$. Allele proportions in white and non-white people were not statistically different (patients, $\mathrm{p}=0.078$; controls, $\mathrm{p}=0.713$ ).

Hcy concentration was analyzed according to gender, race/colour and age. Males presented the most increased Hcy concentrations in both patients $(M=$ 23.23 $\pm 8.01 ; F=17.52 \pm 7.30 ; p=0.004)$ and control group $(M=19.73 \pm 7.71 ; F=13.80 \pm 3.35 ; p=0.0010)$. No diff e $r-$ ence between white and non-whites was observed.

The level of total plasma homocysteine was significantly higher in $A D$ patients $(18.3 \mu \mathrm{M} / \mathrm{L} \pm 7.6)$ than in controls $(15.3 \mu \mathrm{M} / \mathrm{L} \pm 5.4 ; p=0.02)$. Hcy was also analyzed according to MTHFR genotypes distributions (Table 3). No significant increase in Hcy level as was theoretically supposed for both 677TT and $1298 \mathrm{CC}$ people were observed. An unexpected inc rease on Hcy level was observed in 1298AA $(p=0.03)$.

\section{DISCUSSION}

Of the several biosocial-demographic features analyzed in this study, only ethnic origin (white/nonwhite), dementia family history and smoking habit were statistically different in AD patients and controls. Smoking habit is an adquired factor which inc reases the susceptibility for vascular diseases but difference between them could not be attributed to subtypes of $A D$ because probable and possible $A D$ we re not diffe rent as to the prevalence of smokers and controls had more smokers than patients. It has been stablished that high values of homocysteine and $A D$ result from the interaction of adquired and genetic factors.

The re is considerable epidemiologic evidence of increased plasma Hcy levels in elderly people, whether normal or cognitively impairs ${ }^{22,23}$, including $A D^{17,24}$. In this communication, we present data supporting the association between Hcy plasmatic concentration and AD. According Postiglione et al..$^{25}$ hyperhomocysteinemia is related to the progression and increas- ing severity of $A D$. Because inadequate blood levels of folate, B12 and B6 vitamins are responsible for ap proximately two-thirds of the hyperhomocysteinemia cases ${ }^{26}$, the bad nutritional status which accompanies the pro $g$ ressive severity and long duration of $A D$ would, perhaps explain a great number of $A D$ patients with increased Hcy level.

Genetically, we studied the contribution of the polymorphisms C677T and A1298C of the MTHFR gene in plasma concentration of Hcy and in the development of $A D$, since this enzyme is involved in Hcy metabolism.

The mutation of C677T in MTHFR gene produces an enzyme which has a catalytic activity of $30 \%$ and $40 \%$ in carriers of TT and CT genotypes, respectively, as compared with CC genotype ${ }^{27}$. In A1298C MTHFR polymorphisms, although the enzyme is not a thermolabile protein, the catalytic activity is also shorter among homozygous CC. Enzymatic deficiency may result from MTHFR polymorphisms and develop $A D$ and hyperhomocysteinemia, but our data did not confirmthis hypothesis because no significant difference was observed in genotypes distributions and alleles frequencies between our AD patients and controls.

Because the mixing of white and blacks is more intense in the North and in the Northeast of Brazil (white 29\%; non-white $71 \%$ ) than in other regions of the country and also because genotypes may differ according to ethnicity, the individuals in the two $g$ roups were also compared as to race/color. The proportion of $\mathrm{CT}+\mathrm{TT}$ was significantly higher in white AD patients $(72 \%)$ than in non-white $(\sim 31 \% ; p=0.014)$. Scientific literature shows that, in fact, the shortest $677 T T$ genotype frequencies are among blacks ${ }^{28,29}$. However, data failed in confirming the same results for controls, maybe due to the smaller proportion of whites in the control group.

In the population from Pernambuco ( $n=42$ patients; $n=50$ controls) 677 T allele frequencies were $37 \%$ in patients and $27 \%$ in controls. In the population from Rio Grande do Sul ( $n=30$ patients; $n=30$ controls), a south Brazilian State where Caucasians are more frequent ${ }^{30}, 677 \mathrm{~T}$ allele frequencies were $35 \%$ in patients and $29 \%$ in controls. There was no statistically significant difference between both populations. We suppose that a study involving a bigger sample and a better definition of ethnic origin by molecular markers might account for these contradictories data.

We could not associate MTHFR genotypes with 
Hcy, except in 1298AA individuals. Although higher male/female relation may explain some elevated Hcy concentration in controls, 677T allele seems to contribute for this result. In order to test this supposition we excluded 1298AA individuals who were $677 T$ simultaneously from the data and then, the means were diminished and the difference between patients $(15.25 \mu \mathrm{M} / \mathrm{L} \pm 4.47)$ and controls $(14.54 \mu \mathrm{M} / \mathrm{L} \pm 3.51)$ became insignificant $(p=0.66)$.

Our results are in agreement with similar studies in Sweden ${ }^{31}$, in UK ${ }^{32}$, in Italy ${ }^{14,15}$ but association between Hcy and $A D$ is not consensual even in other European and American populations s $^{433}$.

Taking all the above mentioned into consideration, it is possible that others genetic factors involving Hcy metabolism, as mutations on metionina sintase, folate receptor among others, have stronger effect on AD and Hcy than MTHFR loci. Environmental factors such as nutritional deficiency of folate, vitamin B6 and B12 may also contribute to incre ase the Hcy levels in $A D$ patients as such genetic factors.

As limitations of this study, we can point out the small size of the sample, particularly the number of white people in the control group and the failure to evaluate the nutritional status of patients and controls by determining concentrations of folate, $\mathrm{B} 6$ and B12 vitamins in plasma. Our data confirm the association between plasma Hcy level and $A D$ and suggest that C677T and A1298C MTHFR polymorphisms do not contribute to genetic susceptibility for Alzheimer's disease in elderly individuals in the northeast of Brazil.

\section{REFERENCES}

1. Goyette P, Sumner JS, Milos R, et al. Human methylenetetrahydrofolate reductase: isolation of cDNA, mapping and mutation identification. Nat Gen 1994;7:195-200.

2. Van der Put NMJ, Gabreels F, Stevens EMB, et al. A second common mutation in the methylenetetrahydrofolate reductase gene: an additional risk factor for neural-tube defects? Am J Hum Genet 1998;62:10441051.

3. Kang SS, Zhou J, Wong PWK, et al. Intermediate homocysteinemia: a thermolabile variant of methylenetetrahydrofolate reductase. Am J Hum Genet 1988;43:414-421.

4. Andreassi MG, Botto N, Battaglia FCD, et al. Methylenetetrahydrofolate reductase gene C677T polymorphism, homocysteine, vitamin B12, and DNA damage in coronary artery disease. Hum Genet 2003;112:171-177.

5. Christen Y. Oxidative stress and Alzheimer disease. Am J Clin Nutr 2000;71(Suppl):S621-S629.

6. Goedert M. Tau protein and the neurofibrillary pathology of Alzheimer's disease. Trends Neurosci 1993;76:460-465.

7. Lovestone S, Anderton B. Cytoskeletal abnormalities inAlzheimer's disease. Curr Opin Neurol Neurosurg 1992;5:883-888.

8. Kang J, Lemaire HG, Unterbeck A, et al. The precursor of Alzheimer's disease: amyloid A4 protein resembles a cell-surface receptor. Nature 1987;325:733-736.

9. Clarke R, Smith AD, Phil D, et al. Folate, vitamin B12, and serum total homocysteine levels in confirmed Alzheimer disease. Arch Neurol 1998; 55:1449-1455.
10. Religa D, Stycz M, Peplonska B, et al. Homocysteine, apolipoproteine $\mathrm{E}$ and methylenetetrahydrofolate reductase in Alzheimer's disease and mild cognitive impairment. Dement Geriatr Cogn Disord 2003;16: 64-70.

11. Kluijtmans LA, Young IS, Boreham CA, et al. Genetic and nutritional factors contributing to hyperhomocysteinemia in young adults. Blood 2003;101:2483-2488.

12. Anello G, Gueant-Rodriguez RM, Bosco P, et al. Homocysteine and methylenetetrahydrofolate reductase polymorphism in Alzheimer's disease. Neuroreport 2004;15:859-861.

13. Ho PI, Ashline D, Dhitavat S, et al. Folate deprivation induces neurodegeneration: roles of oxidative stress and increased homocysteine. Am J Clin Nutr 2003;61:560-565.

14. Zuliani G, Ble A, Zanca R, et al. Genetic polymorphisms in older subjects with vascular or Alzheimer's dementia. Acta Neurol Scand 2001; 103:304-308.

15. B runelli T, Bagnoli S, Giusti B. The C677T methylenetetrahydrofolate reductase mutation is not associated with Alzheimer's disease. Neurosci Lett 2001;315:103-105.

16. Wakutani $\mathrm{Y}, \mathrm{Kowa} \mathrm{H}, \mathrm{Kusumi}$ M, et al. Genetic analysis of vascular factors in Alzheimer's disease. Ann NY Acad Sci 2002;977:232-238.

17. McKahann G, Drachmann D, Folstein M. Clinical diagnosis of Alzheimer disease: report of the NINCDS-ADRDA Work Group under the auspices of Department of Health and Human Services Task Force on Alzheimer's disease. Neurology 1984;34:939-944.

18. Pfiffer CM, Huff DL, Gunter EW. Rapid and accurate HPLC assay dos pIAM total homocysteine and cysteine in a clinical laboratorysetting. Clin Chem 1999;454:290-292.

19. F rosst $\mathrm{P}, \mathrm{Pai} \mathrm{A}, \mathrm{Milos} \mathrm{R}$, et al. A candidate genetic risk factor for vascular disease: a common mutation at the methylenetetrahydrofolate reductase locus. Nat Gen 1995; 10:110-113.

20. Skibola CF, Smith MY, Kane E, et al. Polymorphisms in the methylenetetrahydrofolate reductase gene are associated with susceptibility to acute leukemia in adults. Rev PNAS 1999;96:12810-12815.

21. Esiri MM, Wilcock GK, Morris JH. Neuropathological assessment of the lesion of significance in vascular dementia. J Neurol Neurosurg Psychiatry 1997;63:749-753.

22. Bell IR, Edman JS, Selhub J, et al. Plasma homocysteine in nonvascular dementia of depressed elderly people. Acta Psychiatr Scand 1992; 86:386-390.

23. Morris MS, Jacques PF, Rosenberg IH, et al. Hypehomocysteinemia associated with poor recallin the third National Health and Nutrition Examination Survey. Am J Clin Nutr 2001;73:927-933.

24. Seshadri S, Beiser, A, Selhub J, et al. Plasma homocysteine as a risk factor for dementia and Alzheimer's disease. N Engl J Med 2002;346: 476-483.

25. Postiglione A, Milan G, Ruocco A, et al. Plasma folate, vitamin B12 and total homocysteine and homozygosity for the C677T mutation of the 5,10-methylenetetrahydroblate reductase gene in patients with A lzheimer's dementia. Gerontology 2001;47:324-329.

26. Selhub J, Mlller JW The pathogenesis of homocysteinemia: interruption of the coordinate regulation by S-adenosylmethionine of the remethylation and transulfuration of homocysteine. Am J Clin Nutr 1991;55:131-138.

27. Ulrich CM, Yasui Y, Storb R, et al. Pharmacogenetics of methothrexate: toxicity among marrow transplantation patients varies with the methylenetetrahydroblate reductase C677T polymorphism. Blood 2001;98: 231-234.

28. Dilley A, Austin H, Hooper WC, et al. Relation of three genetic traits to venous thrombosis in an African-American population. Am J Epidemiol 1998;147:30-35.

29. Pepe G, Venegas CO, Giusti B, et al. Heterogeneity in world distribution of the thermolabile C677T mutation in 5-10-methylenetetrahydrofolate reductase. Am J Hum Genet 1998;63:917-920.

30. Fernandez LL, Scheibe RM. Is MTHFR polymorphism a risk factor for Alzhimer's disease like APOE ? Arq Neuropsiquiatr 2005;63:1-6.

31. Prince JA, Feuk L, Gottfries J, et al. Lack of replication of association finings in complex disease: an analysis of 15 polymorphisms in prior candidate genes for sporadic Alzheimer's disease. Eur J Hum Genet 2001;9:437-444.

32. Tysoe C, Galinsky D, Robinson D, et al. Analysis of alpha-1 antichymotrypsin, presenilin-1, angiotensin-converting enzyme, and methylenetetrahydrofolate reductase loci as candidates for dementia. Am J Med Genet 1997;74:207-212.

33. Kluijtmans LA, Kastelein JJ, Lindemans J, et al. Thermolabile methylenetetrahydrfolate reductase in coronary artery disease. Circulation 1997;96:2573-2577. 